\title{
絶緑信頼性とその事例
}

\author{
高木 清****
}

\section{The Insulation Reliability of PWB's and Their Failure Examples}

\author{
Kiyoshi TAKAGI*,**
}

\footnotetext{
* NPO 法人サーキットネットワーク（～247-0008＼cjkstart横浜市栄区本郷台 4-12-10）

**高木技術士事務所（† 247-0008 横浜市栄区本郷台 4-12-10)

* NPO Circuit Network (4-12-10, Hongodai, Sakae-ku, Yokohama 247-0008)

** TAKAGI Associates (4-12-10, Hongodai, Sakae-ku, Yokohama 247-0008)
}

\section{1.はじめに}

エレクトロニクス産業は限りない進展をしており，巨大 なクラウドシステム, 小型のスマートフォンを始め, ロ ボット, 医療関連機器, その他, 私どもの生活に深く浸入 し，情報は巨大なネットワークを形成している。これらは すべて電気信号により処理され，その電気信号は集積化さ れた半導体素子を中心に組み立てられた電子回路より成り 立っている。電子回路はプリント配線板上に多くの部品を 搭載，接続されることにより作られている。この接続を 行っているプリント配線板の配線の絶縁不良によりシステ ムダウンが発生すると, 想像出来ない事態を招きかねない という事で, 絶縁の確保は非常に重要なことである。ここ で扱う有機樹脂プリント配線板はベアチップの半導体チッ プを搭載するパッケージ基板とモジュールを構成する通常 のプリント配線板がある。その絶縁信頼性を向上させるた めの試験法，不良事例を紹介する。

\section{2. プリント配線板の配線ルール}

絶縁特性に関係する因子の一つとして, 絶縁間隙があ る。プリント配線板は非常に多くの分野で使われているの で，表 1 の如く，配線ルールも多くのものがあるが，先端 の機器に使用される高密度配線のものは表の超々高密度レ ベルの微細間隙を持つものが多い。しかし, 高電圧用の機 器の導体パターン間には高電圧が印加され, 正常な絶縁を

表 1.プリント配線板の配線ルール

\begin{tabular}{l|c|c|c|c}
\hline \multicolumn{1}{c|}{ 項 } & 一般レベル & 高密度レベル & $\begin{array}{c}\text { 超高密度 } \\
\text { レベル }\end{array}$ & $\begin{array}{c}\text { 超々高密度 } \\
\text { レベル }\end{array}$ \\
\hline ライン幅 & $150 \sim 100 \mu \mathrm{m}$ & $70 \sim 49 \mu \mathrm{m}$ & $30 \sim 10 \mu \mathrm{m}$ & $15 \sim 3 \mu \mathrm{m}$ \\
\hline ライン間隙 & $150 \sim 100 \mu \mathrm{m}$ & $80 \sim 50 \mu \mathrm{m}$ & $40 \sim 15 \mu \mathrm{m}$ & $15 \sim 3 \mu \mathrm{m}$ \\
\hline 導体厚 & $25 \sim 15 \mu \mathrm{m}$ & $20 \sim 15 \mu \mathrm{m}$ & $20 \sim 10 \mu \mathrm{m}$ & $20 \sim 5 \mu \mathrm{m}$ \\
\hline ビア径 & $200 \sim 100 \mu \mathrm{m}$ & $120 \sim 60 \mu \mathrm{m}$ & $40 \sim 20 \mu \mathrm{m}$ & $40 \sim 20 \mu \mathrm{m}$ \\
\hline ランド径 & $400 \sim 200 \mu \mathrm{m}$ & $300 \sim 150 \mu \mathrm{m}$ & $100 \sim 60 \mu \mathrm{m}$ & $70 \sim 40 \mu \mathrm{m}$ \\
\hline 層間間隙 & $200 \sim 40 \mu \mathrm{m}$ & $80 \sim 30 \mu \mathrm{m}$ & $50 \sim 15 \mu \mathrm{m}$ & $30 \sim 10 \mu \mathrm{m}$ \\
\hline 全板厚 & $2,000 \sim 400 \mu \mathrm{m}$ & $1,200 \sim 300 \mu \mathrm{m}$ & $800 \sim 80 \mu \mathrm{m}$ & $800 \sim 50 \mu \mathrm{m}$ \\
\hline 層数 & $4 \sim 10$ 層+ & $6 \sim 20$ 層+ & $6 \sim 40$ 層+ & $6 \sim 15$ 層+ \\
\hline
\end{tabular}

保つためには印加電圧に応じた間隙を必要とする。

間隙は外層，内層のパターンの面方向と厚さ方向の層間 間隙とがあり，いずれも考慮する必要がある。

\section{3. 絶縁体の構造と影響する因子}

有機樹脂プリント配線板では主要の絶縁基板は銅張積層 板と接着シートであるプリプレグ，および，ビルドアップ プリント配線板用の絶縁層材料である。

銅張積層板は絶縁樹脂と基材のガラス布，および，フィ ラー粒子，銅筞より構成されている。樹脂としてはエポキ シ樹脂が多いが, 要求特性により, 耐熱性の高いイミド樹 脂や, 低誘電率材であるテフロン樹脂や各種の変成樹脂な どが用いられている。何れも樹脂自体は相当絶縁性の高い ものである。絶縁性は接着状態が大きく影響するが，その 箇所は接着界面で，樹脂と銅䈃，樹脂とフィラー，樹脂と ガラス布繊維間などである。

水分が存在しないとエレクトロケミカルマイグレーショ ン（以下 ECM）による絶縁劣化は起きないと考えている。 樹脂の絶縁性の低下に影響する因子である ECM は吸湿に よる水分, 水溶性のイオン, イオンが移動する微細な間 隙，および，イオンを駆動する電位（電界）の存在がある ことと考えている。さらに，樹脂が外部要因で，変質して いるような場合にはこれらによる絶縁性は変化する。

\section{4. 絶縁信頼性の試験法}

通常の環境であれば絶縁材料が加湿され，絶縁劣化が起 こることは想定出来ないが, 特殊な環境, 例えば

高湿度の環境

海岸，海上などの塩分などのイオン性成分を含む環境 温泉地带など硫化水素など腐食性成分を含む環境 などでは，保護コーティングされていないプリント配線板 やプリント回路実装基板などは急速に腐食が進行し劣化す る。ここではこのような環境については触れず，通常環境 における絶縁を考える。 
表 2. 加湿試験法

(1)

\begin{tabular}{|c|c|c|c|c|c|c|c|c|}
\hline \multirow{4}{*}{ 温湿度定常試験 } & & $\begin{array}{l}\text { 温度 } \\
\left({ }^{\circ} \mathrm{C}\right)\end{array}$ & $\begin{array}{c}\text { 湿度 } \\
(\% \mathrm{RH})\end{array}$ & \multicolumn{4}{|c|}{ 試験時間 (h) } & \multirow{4}{*}{$\begin{array}{l}\text { 初期および } \\
\text { 中間, 最終時に } \\
\text { 外観検查, 絶縁抵抗 } \\
\text { 測定 }\end{array}$} \\
\hline & JPCA-ETO2 & 40 & 93 & 168 & 500 & 1,000 & $(2,000)$ & \\
\hline & JPCA-ETO3 & 60 & 90 & 168 & 500 & 1,000 & $(2,000)$ & \\
\hline & JPCA-ETO4 & 85 & 85 & 168 & 500 & 1,000 & $(2,000)$ & \\
\hline
\end{tabular}

(2)

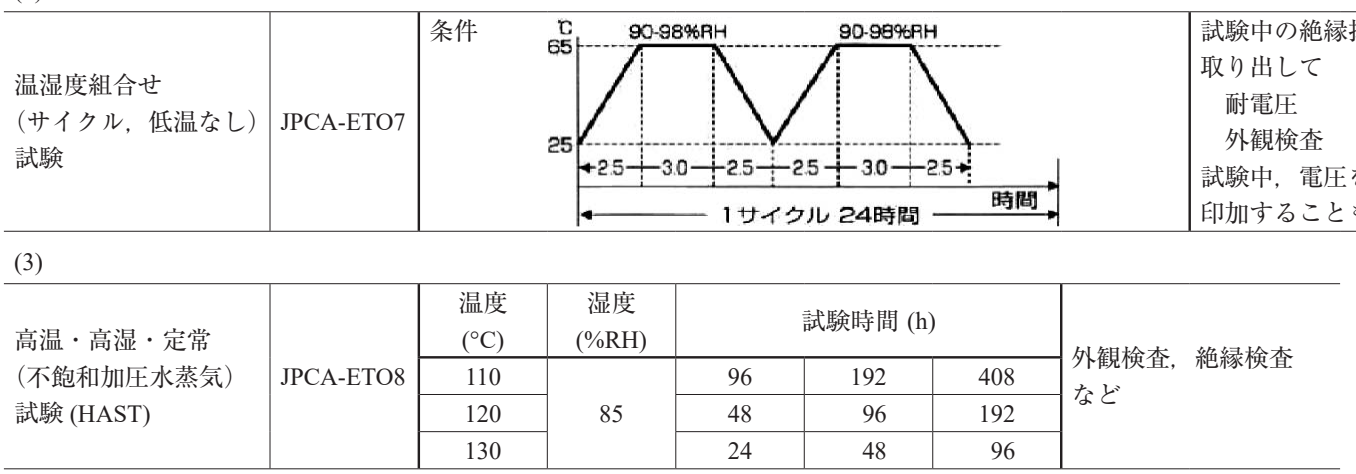

IEC 60749 Amendmentl: Semiconductor devices - Mechanical and climatic test methods SC: Dampheat, Steady-State-highly accelerated JIS C 60068-2-66:2001「環境試験方法一電気・電子一高温高湿，定常（不飽和加圧水蒸気）」(IEC60068-2-66)

IEC 60068-2-66 Environmental testing-Part2: Test methods- Cx: Damp heat, steady state (unsaturated pressurized vapor)

絶縁劣化の発生する条件として, (1)電極間に電位があ る，(2)その間にイオンが移動する微細な間隙がある（表面 も間隙の一つ), (3)イオン化する溶媒（水分）がある, (4) イ オン性物質があると考えられる。これは電気化学現象とし て捉えられる。ここで, 電位は外部よりの印加電圧, ある いは，自然電極電位の金属イオン溶出の電位である。

絶縁信頼性を評価する場合には加速加湿環境での絶縁劣 化を評価する。その試験環境は表 2 のようをもの゙ある。 この表は JPCA 規格 ${ }^{1)} よ り$ 編集したものである。

大気下で使用される試験法ではこの表のうち,

$85^{\circ} \mathrm{C}, 85 \% \mathrm{RH}$ （必要に応じ電圧を印加する）

の条件で試験されることが多い。時間は 500〜1,000 時間程 度を指定する仕様が多いが, 寿命の尽きるまで長時間の試 験を行うこともある。この条件は実際の環境での条件より 厳しいが大気中で出来る試験条件である。したがって, 非 常に多くの過去のデータがあり, 比較することが可能であ るが, この条件でも結果がでるまで長時間を要する。

この加速環境での試験が実際の装置の何年分になるかを 推定する加速率を求めることは非常に難しい。公表されて いる值として, 和嶋の膨大な研究の報告がある ${ }^{2)}$ 。この試 験に於いてガラスエポキシプリント配線板の試料の劣化に ついて, 長時間にわたり調査を行ない, 膨大なデー夕より 寿命推定式を導びいている。これより実使用環境 $\left(35^{\circ} \mathrm{C}\right.$, $75 \%$ RH 5 V 印加）のものを寿命 15 年とすると, 加速試験 $\left(85^{\circ} \mathrm{C}, 85 \% \mathrm{RH} 100 \mathrm{~V}\right.$ 印加 $)$ での寿命試験は 90 時間でよい ことを示している。

それでも, 結果を早く知るために, 不飽和加圧水蒸気試 験 (通常, HAST (Highly Accelerated humidity and temperature Stress Test) という）が用いられている。その条件は

$130^{\circ} \mathrm{C}, 85 \% \mathrm{RH}$ （必要に応じ電圧を印加する）
を使用することが多くなっている。この条件では比較的短 時間で結果を得ることは出来るが, 多くの問題がある。こ の点については後述する。

\section{5. 絶縁劣化の事例}

プリント配線板の絶縁不良は加湿環境での ECM である。 絶縁材料の不具合, 製造での污染その他の種々な原因で発 生する絶縁不良は機器の動作不良を引き起こすことにな る。大きな損害になるので発性の原因を追及することは重 要である。このような絶縁障害は実際に遭遇したものにつ いての原因を追及すことは難しいが, 出来る限り試料を採 集, 解析し発生の原因を知り, 対策することが有用であ る。以下に事例を紹介する。

\section{1 プリント回路実装基板の焼損事故の例}

図 1 はプリント回路実装基板の破損した例である。(a) は 絶縁不良によりショートし, 高温で絶縁基板が炭化したも ので，焼損直前の状態である。(b) は実際に焼損したもの で，事故に直結するものである。

このような状態では解析は不可能であるが, 絶縁基板内 での絶縁劣化によると推定できる。実際に発生すると機器 のシステムの不具合に通じ重大な欠陥である。

\subsection{CAF (Conductive Anodic Filament)}

図 2 に模式図を示したが, 銅張積層板基材のガラス布の 繊維に沿って発生するエレクトロケミカルマイグレーショ ンの一種である ${ }^{3)}$ 。機械的ドリルで穴あけするので, 図 3(a) のように穴壁より 25〜30 $\mu \mathrm{m}$ のガラス瀻維にほつれが生 じ，この程度の長さまでの処理液の浸透は容認されてい る。しかし, 初期には図 3(b) の上うに纎維に沿って相当の 長さに浸透するものが観測された。樹脂をガラス布の瀻維 束の中まで含浸させることは難しく, 樹脂を含浸したプリ 


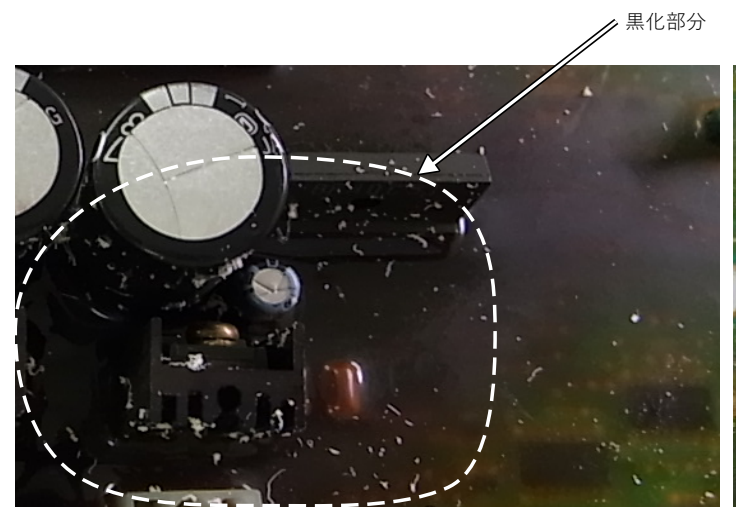

(a) 発熱で絶縁基板が黒化 （焼損直前状態）

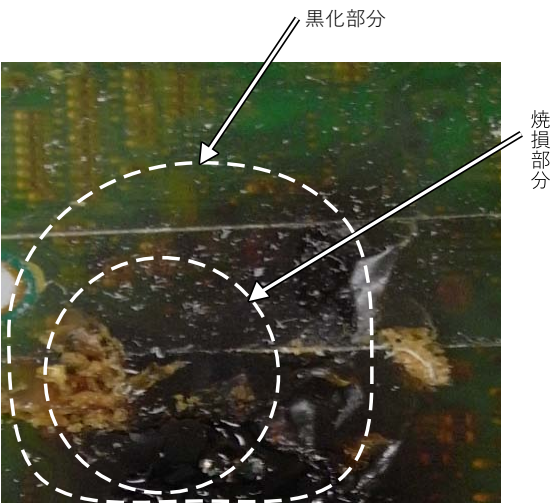

(b) 焼損により破壊

図 1. プリント回路実装基板の焼損事故例
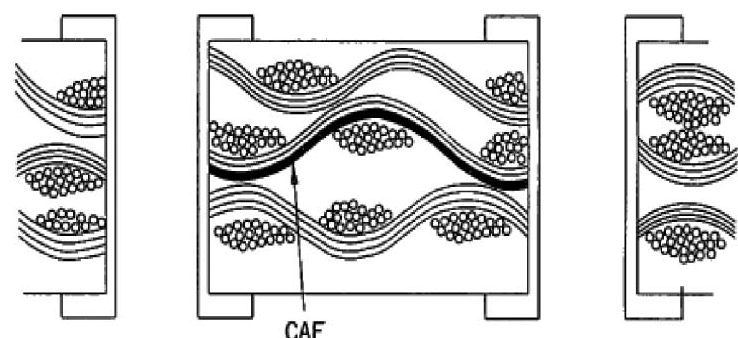

図 2. CAF の発生状況の模式図
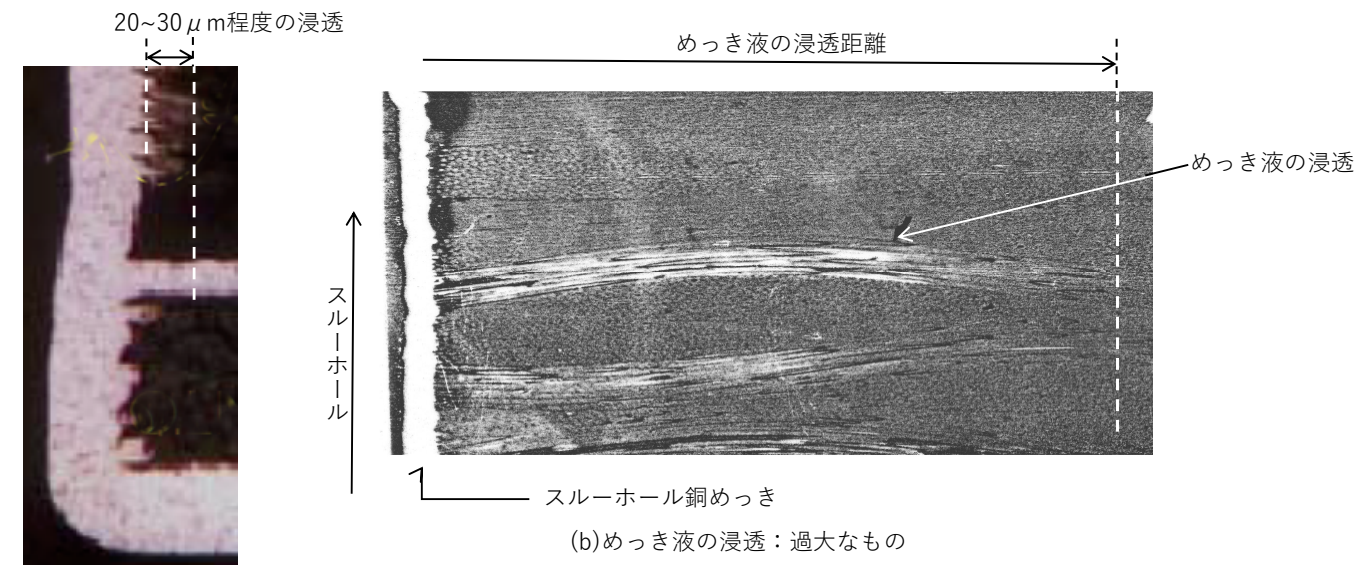

(b)めっき液の浸透：過大なもの

(a)めっき液の浸透：ほぼ正常

図 3. めっき液のガラス布への液の浸透

プレグで図 4 (a)のように空気の混入したものが多く, ここ に液が浸透するので, 絶縁低下は避けられないものであっ た。その後, 開繊技術の進展で図 4 (b) のように均一な含浸 が可能になり, カップリング材の開発とともに飛躍的に絶 縁性能は向上した ${ }^{4)}$ 。このような開発は日本で進められた もので, 国産品は非常に安定したものとなっている。海外 産はこの点不明確で, 使用に当って十分な調査が必要であ る。しかし, 高密度化, 微細化により, ごく僅かの繊維に 沿った CAF が発生することがある。図 5 にその例を示し た ${ }^{5)}$ 。これに対処したガラス布繊維や積層板について国内 では高度化の研究が進められている。

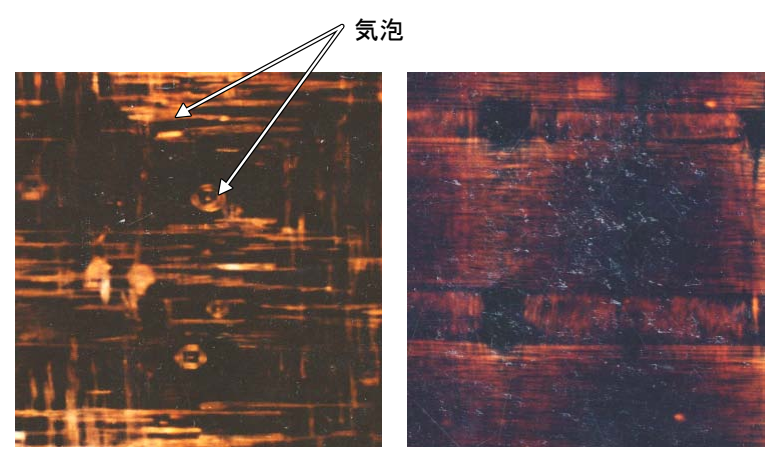

(a)含浸不良

(b)良好な含浸状態

図 4. ガラス布繊維と樹脂の含浸状態 


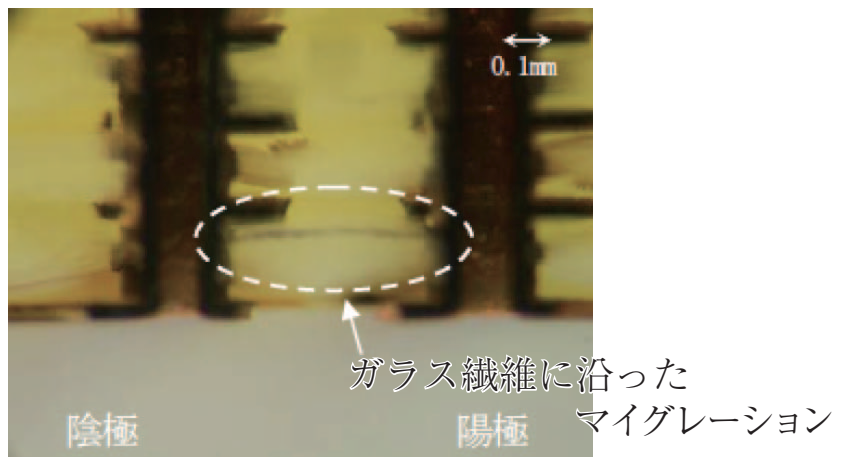

図 5. スルーホール間をショートしたCAF の例

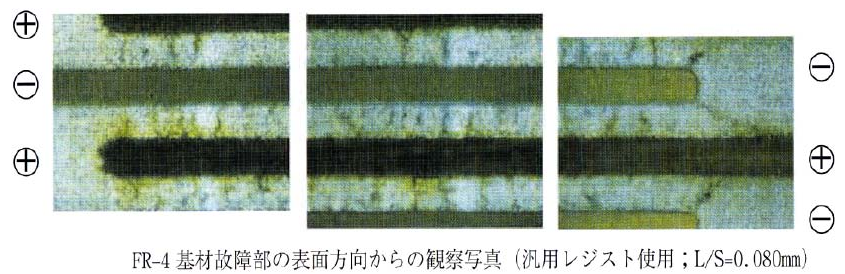

図 6. 加湿により顕在化した欠陥・絶縁体表面のマイグ レーション (a) 内層のマイグレーション

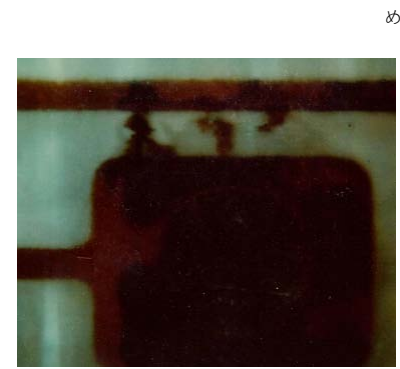

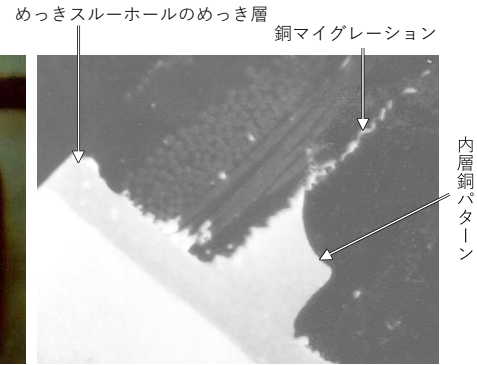

(b) 内層のマイグレーションの断面
図 7. 内層パターン間のマイグレーション

\section{3 面内のパターン間ショート}

図 6 は加湿試験によりプリント配線板の表面に発生した マイグレーションによるショートの例である。原因とし て, 絶縁基板表面に残留した污染物質, 基板内の不純物な どによると推定される。パターン間隙がより小さくなって いるので, 絶縁基板の選択, プリント配線板の処理法, 取 り扱い法など厳しい管理が必要になる。

\section{4 内層パターン間のショート}

図 7 は加湿試験によりショートしたことで故障を起こし たプリント配線板を調查したものである。内層がショート しており, 解析の結果, 銅箔の最終表面処理のクロメート 被膜により樹脂との密着力が小さくなって微小な剥離がで き, 吸湿によりこの空間にめっきスルーホールのめっき残 椬よりカリウムイオンのマイグレーションがあり, クロ メートよりのクロムイオン, および, 樹脂中に残留し, 溶 出した塩素イオンにより銅箔が浸食され, 対極に析出, 短 絡に至ったものであるの。その後, クロメートの被膜は非 常に薄くなり, 樹脂中の残留塩素も極力抑えられ, また,
銅めっきはピロリン酸銅浴に代わり，より優れた硫酸銅浴 を使用することにより, 発生は防止された。この例は絶縁 劣化段階で故障箇所を発見することができ，解析したので 原因の追求が出来たものである。

この例は古いデータであるが，使用する材料，処理法な どの組み合わせで考えられない故障が発生することも考え られるので，今後の参考として例示したものである。

\section{HAST の問題}

ここ十数年, 有機樹脂プリント配線板のユーザは加速絶 縁劣化試験の条件として, HAST による, $130^{\circ} \mathrm{C}, 85 \% \mathrm{RH}$ （必要に応じ電圧を印加する）を指定することが多い。短い 試験時間で結果がでるということで，この試験が好まれて いる。しかし，この試験は半導体パッケージの封止材を通 しての半導体チップの試験法として用いられたもので, 有 機樹脂の封止材その物を対象にしたものではない7)。それ が，いつの間にか有機樹脂製品の試験に転用されたもの で，加速劣化試験として適当なものであるかの検討は殆ん ど行なわれていない。

この試験法は加圧をするオートクレーブ内で水蒸気を加 圧して, 高温にて相対湿度を制御し不飽和環境を実現して いる。 $100^{\circ} \mathrm{C}$ 以上の高温高圧領域に扔いて湿度を直接測定 する標準的な方法はまだ確立されていないので，実際の湿 度の測定は出来ていない。したがって, 加圧下の試験が実 際の使用状況を考えた加速になっているかは不明である。 本来, オートクレーブは化学反応を促進するためのもの で，この条件で積層板が変質することもあるが，考慮され ていない。このような問題があり, 本研究会で検討を行っ た。

本試験で重量変化に注目した。本来, 加湿試験で重量は 減少すること無く, 加湿により増加し，その後飽和して一 定值になる。しかし，実際には図 8 (a) ( ) $^{8}$ では積層板の種類 により著しく減少するものがある。減少の原因を広く検討 し, 要因を分離, 解析したものが図 8 (b) $)^{9}$ で, 重量変化が 樹脂の熱分解によることがわかる。図 8 (c) $)^{9)}$ は過剩の HAST による樹脂の分解した状況を示したものである。

これより，この試験の有効時間は樹脂の分解までの時間 より短い時間となり，この間のデー夕は参考となり得る が，これを超えた時間のデー夕は意味がない。この時間は 樹脂の耐熱性に依存すると考えられており，指標としてガ ラス転移点 $(\mathrm{Tg})$ があるが, 個々の積層板についての確認が 必要である。

銅張積層板メーカより HAST の試験結果が公表されてい るが，その結果については保証されていない。プリント配 線板は材料依存性の大きな部品で, 保証しない材料で作る プリント配線板が HAST の結果を保証することが不可能な ことがわかる。

$100^{\circ} \mathrm{C}$ 以下の大気中の環境に近似するために空気を導入 


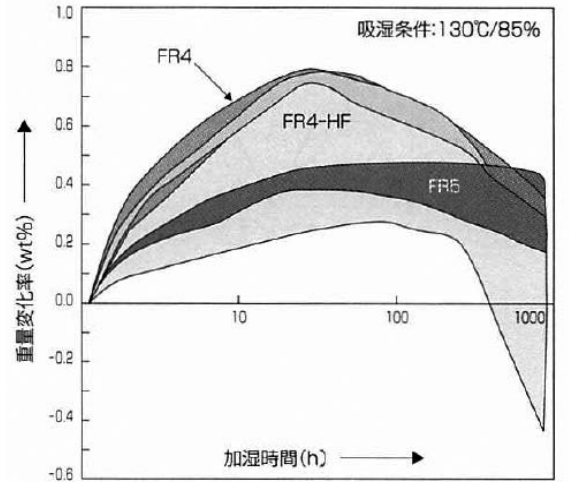

(a) HAST 130\% $/ 85 \%$ RHにおける重量変化

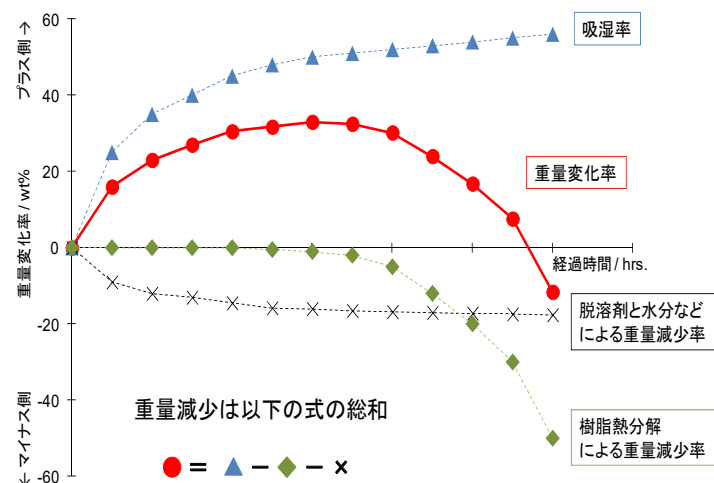

（b）試験時間と重量変化の解析図

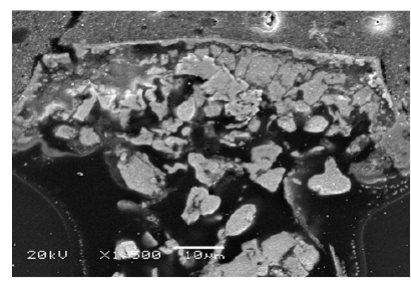

(c) Tg以上でのHAST試験による 樹脂基板の分解状況

図 8. HAST による重量減少

するものとして Air-HAST の試験法も検討されているが, プリント配線板のような樹脂材料系材料は高温での酸素䨌 囲気での Air-HAST は樹脂や銅の酸化を促進する恐れがあ り, 劣化のメカニズムが定かではないため, 適用について は確立されていない。

\section{7. 終わりに}

広く使われているプリント配線板の絶縁性は高密度化で 重要性がより増していることを説明した。現行の試験法, 加速寿命による加速率の算定の困難さ，試験法の選択の一 つとしての HAST のプリント配線板への適用の問題点につ いての説明を行った。

本稿の作成に当って, 新光電気中村氏に資料の提供, コ メントなどの協力を頂いた。

(2018.5.7- 受理)

\section{文献}

1) 日本電子回路工業会：“プリント配線板環境試験方法,” JPCA-ET01 09, 2007

2) 和嶋元世：“信頼性試験の加速率, ” プリント回路ジャーナ ル， 2017.09.20号， p. 4

3) J. P. Mitchel and T. L. Welsher: Conductive Anodic Filament
Growth in Printed Circuit Materials, Proc. PCWC II, Munich, p. 80,1981

4) 高木 清：“よくわかるプリント配線板のできるまで (3 版), ” p. 236, 日刊工業新聞, 2011

5) ECM 研究会：研究会資料 CAF 評価事例, 2008

6) T. Awano, T. Ishikawa, T. Yoshimitsu, and K. Takagi : "Insulation Reliability of Glass Cloth Material Based Copper Clad Laminates," Printed Circuit World Convention IV (Tokyo), WC IV - 47, June $2-5,1987$

7) EIAJ ED-4701/100

8) JIEP : “エレクトロケミカルマイグレーション評価方法研究 会資料,”高密度プリント配線板絶縁性の加速試験法の研 究, p. 41, 2009 年 6 月

9) 中村和裕 : 私信 2018

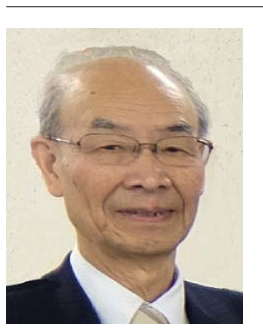

高木 清（たかぎきよし）

1955 年横浜国立大学丁学部卒，同年富士通入社, 1989 年古河電工 (株)，（株）ADEKA 顧問，この 間各種電子材料の開発, 多層プリント配線板の技 術開発に従事，1994 年高木技術士事務所開設，プ リント配線板のコンサルタントに従事, 現在に至 る。

エレクトロニクス実装学会名誉会員,JIEP 前 ECM 研究会幹事, NPO-C-NET 監事, 技術士, 著書「よ くわかるプリント配線板の出来るまで」（日刊工 業新聞社), 他。 